\title{
The Disclosure of Financial and Non-Financial Performance via Narrative Communication: Islamic Bank Annual Report
}

\author{
Fatchul Wachid ${ }^{*}$ Danis Nurul Yunita 2 \\ IIslamic Economic and Finance, Institute of Social Science, Sakarya University, Turkey \\ ${ }_{2}$ Islamic Finance and Management, Business School, Durham University, United Kingdom
}

\begin{abstract}
The main aim of this study is to compare and analyses the financial performance and non-financial analyses related to the corporate governance of Islamic banks, as reported in narrative communication. It also examines the presence of board impression management in leading the company through level optimism, positive emotion, and so on. The data is obtained from the annual report of two Islamic banks, which are BankIslami Pakistan Limited (BIP) from Pakistan and Warba Bank (WB) from Kuwait during 2012-2016. However, the analyses excluding 2014 because WB only provides a report in the Arabic language. Financial and other non-financial aspects comprising of country analysis, company-level analysis and narrative quality analysis are conducted to investigate the effect of how social system covers nation and company culture, governance structure, and management quality influence the performance of Islamic banks. The comprehensive content analysis method is used to measure the suitability of Islamic value and the impact of the non-financial institution; therefore, it can be the main contribution of this paper. The study found, in the financial aspects, WB has better performance that contributes to IFDI indicators and able to provide information about the source and disbursement zakat fund. Further, in non-financial performance found both Islamic banks still lack information in delivering detail contracts via uqud, environmental aspect, and code ethic of the employee. However, BIP poses bad political affairs in corruption level and role-duality within board structure that can contribute to the lack of transparency and the absence of independence.
\end{abstract}

Keywords: Corporate Governance, Islamic Bank, Content Analysis, Islamic Accounting, Ethical Disclosure

\section{Introduction}

Nowadays, the fundamental development of annual report components still followed the conventional accounting even though it is used by Islamic institutions that inform its company profile, financial position, operational result, and its performance. Their annual report values are also absent with the issues of justice, ethics, and other social-environmental. However, some prior research try to formulate some items concerning Islamic value information that comply with sharia regulation in the source and fund expenditure, permissible and restriction product offers by Islamic bank, suitability contract based on Islamic law, and the role of governance organs of Islamic bank.

The present study has been undertaken with the purpose of analyzing various aspect that covers financial and non-financial factors of Islamic Bank annual report in Pakistan and Kuwait using general disclosure checklist by AAOIFI, and social ethical disclosure checklist by Belal et al. (2015). This study also analyzes the presence of impression management, self-presentational dissimulation, and retrospective sense-making through a narrative statement on each Islamic bank's annual report. The paper addresses two research questions:

\footnotetext{
${ }^{*}$ Corresponding author at Kemalpaşa Esentepe Kampüsü, Üniversite Cd., 5405o Serdivan/Sakarya, Turkey. Email: fatchul.wachid@gmail.com
} 
1. How did Islamic banks differ in their level of compliance with AAOIFI and IFSB disclosure requirements?

2. How did the tools of Islamic banks such as governance bodies, contract of product, and prohibited funds are treated and suitable with sharia regulation?

Therefore, this research has a contribution in clarifying its Islamic bank position, whether they have reflected the value of Islamic law by using scrutiny content analysis process from various guidelines. This finding also gives insight on the socio-political and economic context in which these disclosures take place. Hence, it can have a positive impact on their customers and investor in increasing trust and also profitability.

Above aforementioned statement is interesting to note due to investigate external circumstance of Islamic Bank that can affect their achievement. In the level country analysis, six dimensions are used as a proxy to measure legal institutions and environment factors such as voice and accountability, political stability and the absence of violence/terrorism, government effectiveness, regulatory quality, the rule of law, and control corruption. Remain on these factors, cultural dimensions that can influence culture organizational performance are also explained in the following section using Hofstede's insight. On the other hand, this study attempt to investigate internal factors in the company level including the clear basic roles, responsibility among Sharia Supervisory Board, Internal and External Auditor and Board of Director (educational background, prior work experience, turnover periods and duality role) that shows in the following Table 1. Furthermore, an ownership structure that figures out from the involvement of a board director in the ownership of company shares percentage (Abdelsalam, 2015).

Table 1.

Primary Roles of Governance Bodies in Islamic Financial Institutions

\begin{tabular}{|c|c|}
\hline Governance Organ & Role \\
\hline Board of Directors & $\begin{array}{l}\text { - Set and approve overall policy and strategy } \\
\text { - Monitor progress toward corporate objectives } \\
\text { - Ensure accountability of the management } \\
\text { - Protect Shareholders and Investment depositors rights }\end{array}$ \\
\hline Sharia Supervisory Board & $\begin{array}{l}\text { - Set Sharia-related rules and principles } \\
\text { - Provide a clearance of Sharia compatibility of all products } \\
\text { - Oversee compliance and its verdict as to create confidence with respect to } \\
\text { compatibility with Sharia }\end{array}$ \\
\hline Internal Control & $\begin{array}{l}\text { - Ensure management oversight } \\
\text { - Recognize and assess risks } \\
\text { - Detect problems and correct deficiencies }\end{array}$ \\
\hline Internal Audit & - Ensure that the policies set by the board are followed by the management \\
\hline External Audit & $\begin{array}{l}\text { - Ensure the accuracy of the quality and quantity of information } \\
\text { - Ensure that the financial statements are prepared according to the accepted } \\
\text { reporting standards } \\
\text { - Ensure that the profit has been derived without the violating the teachings of Sharia }\end{array}$ \\
\hline Audit Committee & $\begin{array}{l}\text { - Review and supervise the financial reporting } \\
\text { - Provide oversight of internal and external auditors }\end{array}$ \\
\hline Compensation Committee & - Monitor the compensation policy of senior management and key personnel \\
\hline Nomination Committee & $\begin{array}{l}\text { - Provide assessment of the Board of Directors' performance } \\
\text { - Replace board members }\end{array}$ \\
\hline
\end{tabular}

Sources: (Chapra and Ahmed, 2002)

This paper serve different analysis method, data sample and scope explanation with prior research as most of them focus on the ownership structure, board composition, impression management, and ethical identity and reporting corporate social disclosure in several countries such as Bangladesh, Dubai, Egypt, Bahrain (Abdelsalam, 2015; Belal et al., 2015; Al-Ajmi, 2009). Similar study that explore the disclosure of Islamic value conducted by Belal et al. (2015) using comparative method between conventional accounting disclosure requirement and AAOIFI requirement that used data from 19932000. 


\section{Literature Review}

\section{Issues of Disclosure in Islamic Bank Annual Report}

In general accounting, the presence of an annual report is mandatory in making a decision as to the main source of information for the investor, auditor, and other stakeholders. The common annual report consists of some information criteria, which are Chairmans' letter, the directors' report, the financial statement, auditors' report, and other sets of the disclosure. However, Islamic bank institutions still lack permanent items concerning Islamic value information that needs to be disclosed and socialized. Islamic accounting represented by AAOIFI standard is still formulated based on capitalists accounting in the theoretical stage. But, it can be a new beginning to serves a different set of disclosure information is expected to comply with sharia regulation in guiding their entity operation. For disclosure aspects, Islamic accounting should clearly state how the institution is fulfilling its duties and obligations according to Shariah e.g., lawful dealings, zakat and qardh hasan disbursement, permissible and restriction fund allocation, the type of product and service offered by bank and human aspects in terms of morality, ethics and sharia board structure (Haniffa and Hudaib, 2007)

\section{The Influence of Country Level Analysis in Shaping Islamic Bank Performance}

The success of institutional performance can be attributed to from good composition of the legal, environmental, and cultural aspects which often look at corporate governance performance. The set of corporate governance is constructed to create relationships between the company's management to investor relations, customer clients, its board and so on (Chapra and Ahmed, 2002). Kaufmann et al. (2011) constructed six dimensions to measure corporate governance by considering three elements:

1) The process by which governments are selected, monitored and replaced through Voice and accountability $(\boldsymbol{V A})$ that capture citizen's perceptions in government election as well as freedom of expression, freedom of association, and a free media. Political stability and absence of violence/terrorism $(P V)$ - capturing perceptions of the likelihood that the government will be destabilized or overthrown by unconstitutional or violent means, including politicallymotivated violence and terrorism. I

2) The capacity of the government to effectively formulate and implement sound policies illustrate from Government effectiveness (GE) in capturing perceptions of the quality of public services, the quality of the civil service and the degree of its independence from political pressures, the quality of policy formulation and implementation,and the credibility of the government's commitment to such policies. In addition, the regulatory quality $(\boldsymbol{R} Q)$ dimension represents the government ability to formulate and implement private sector development.

3) The respect of citizens and the state for the institutions that govern economic and social interactions among them are breakdown into the Rule of law $(\boldsymbol{R} \boldsymbol{L})$ dimension, which capturing confidence level agent's perceptions in and abide by the rules of society. Particularly, the quality of contract enforcement, property rights, the police, and the courts, as well as the likelihood of crime and violence. Moreover, in investigating country leader that use their power to obtain private gain, including both petty and grand forms of corruption known by Control Corruption (CC) dimension.

In addition, culture is an important factor that able to shape not only the community but also institutions. Culture has been defined as how people think, behave, and response as part of the community. It seems like culture; religion also plays a big role that can influence day-to-day activities in social interaction, including forming organizational structures and practices (Schein, 2004). Nevertheless, this section describes Hofstede's' cultural dimension theory identifying how national cultures affect organizational culture:

1) Power Distance deals with all individuals in societies that have a different level and not equal. This will represent the attitude of the cultural member in responding to new things. The higher value of power distance means that people accept hierarchical order.

2) Individualism illustrates the independency level of members among societies. If the value is lower, it can be considered a collectivist society that has big loyalty or long-term commitment.

3) Uncertainty Avoidance tells about the ability of society to deal with the facts in the future. They try to control the situation rather than conduct sudden incidents. Therefore, high scores in this dimension tend to maintain rigid codes of belief and behavior, not open to new ideas and have an inner urge to be busy and work hard. 
4) The masculinity dimension, which resulted in a high score, indicates that the society encouraged by the presence of competition, standing out from the crowd than prioritize the value of life quality in which refer to Feminine dimensions.

Therefore, those corporate and cultural dimensions can have a better impact on creating a better regulatory environment and transparency, better accountability mechanism, and fairer process for selecting and replacing governments. Regarding Islamic bank performance, it helps the board of directors and other stakeholders in picking up appropriate Islamic bank products and services that can foster their performance.

\section{The Influence of Company Level Analysis in Shaping Islamic Bank Performance}

The relation between the board of director composition and occurrences of financial statement fraud is particularly important to the accounting profession because accountants have a responsibility to identify situations where financial statement fraud has a greater likelihood of occurring. Auditing standards explicitly require auditors to provide reasonable assurance that material financial statement fraud is detected (paragraph .08 of AICPA Statement on Auditing Standards (SAS) No. 53, The Auditor's Responsibility to Detect and Report Errors and Irregularities (AICPA 1989a)). This study's definition of financial statement fraud is limited to two types. Includes occurrences where management intentionally issues materially misleading financial statement information to outside users. The second type contains occurrences of misappropriation of assets by top management. Top management includes the chairperson, vice-chairperson, chief executive officer, president, chief financial officer, and treasurer (Beasley, 1996). In relation to compliance with Sharia, scholars, researchers, and international organizations have all stressed the importance of a Sharia supervisory board (SSB), which can reassure stakeholders that the institution's activities comply fully with Sharia law. The role of SSB and other governance bodies as figure out in Table.1.

\section{Method, Sample and Data Analysis}

In order to shed light on the actual quality of Islamic bank corporate governance practices and their effectiveness in alleviating agency issues in the country and company level, the study uses several methods to explore the presence of sharia compliance, social/ethical aspects, and general corporate disclosure. The data are gathered from two Islamic banks' annual report, which is Bank Islamic Pakistan and Warba Bank during the year 2012-2016. Reffering to test financial performance, this study compares both Islamic banks using CAMEL analysis, which investigates capital adequacy, asset quality, management capability, efficiency, profitability, liquidity, and earning quality.

Moreover, the data analyis method in non-financial factors by using combination of documentary analysis in which content analysis from several disclosure checklist based on AAOIFI, IFSB standards and other relevant literature (attached in the appendices) to measure social and environmental performance and also corporate governance that include ownership structure, and board of directors as well as Sharia governance. Further analysis and comparison are tested in the country level that covers institutional and political environment, culture, and regulation by using Worldwide Governance Indicators (WGI) for the former. Kaufmann et al. (2011) develop six indicators of broad governance dimensions include Voice and Accountability, Political Stability and Absence of Violence/Terrorism, Government Effectiveness, Regulatory Quality, Rule of Law, and Control of Corruption. For the letter in which culture analysis, this study employs Hofstede's insight in assessing cultural dimensions from four primary aspects such as Power Distance, Individualism vs. Collectivism, Uncertainty Avoidance, Masculinity, and Femininity. The comprehensive analysis also conducts in order to look at the presence of impression management, self-presentational dissimulation, and retrospective sense-making from the chairman statement and board of directors' reports that stated in the annual report then evaluate by Diction and LWIC software. The importance of published annual reports is considered as the most consistent way to communicate and construct external image of organization with its stakeholders (Gray, 1988).

\section{Results}

Country Analysis

Legal/Institutional Environment 
Kaufmann et al. (2011) argue the range of the governance indicators are starting from -2.5 to 2.5. From Table 2, it could be seen that there are wide differences score between Kuwait and Pakistan except in the voice and accountability aspect.

Tabel 2 Institutional Condition

\begin{tabular}{|l|c|c|c|c|c|c|c|c|}
\hline \multirow{2}{*}{ Series } & \multicolumn{2}{c|}{$\mathbf{2 0 1 6}$} & \multicolumn{2}{c|}{$\mathbf{2 0 1 5}$} & \multicolumn{2}{c|}{$\mathbf{2 0 1 3}$} & \multicolumn{2}{c|}{$\mathbf{2 0 1 2}$} \\
\cline { 2 - 9 } & Kuwait & Pakistan & Kuwait & Pakistan & Kuwait & Pakistan & Kuwait & Pakistan \\
\hline Control of Corruption & $-0,20$ & $-0,96$ & $-0,23$ & $-0,52$ & $-0,19$ & $-0,86$ & $-0,19$ & $-1,06$ \\
\hline Political Stability & $-0,15$ & $-2,47$ & $-0,21$ & $-2,48$ & 0,17 & $-2,60$ & 0,20 & $-2,68$ \\
\hline Rule of Law & 0,03 & $-0,83$ & 0,00 & $-0,77$ & 0,37 & $-0,86$ & 0,37 & $-0,88$ \\
\hline Voice and Accountability & $-0,69$ & $-0,69$ & $-0,66$ & $-0,72$ & $-0,66$ & $-0,80$ & $-0,64$ & $-0,84$ \\
\hline Government Effectiveness & $-0,18$ & $-0,64$ & $-0,03$ & $-0,67$ & $-0,07$ & $-0,79$ & $-0,07$ & $-0,78$ \\
\hline Regulatory Quality & $-0,07$ & $-0,64$ & $-0,17$ & $-0,63$ & $-0,07$ & $-0,70$ & $-0,04$ & $-0,72$ \\
\hline
\end{tabular}

Source: (World Bank, 2016)

Six aggregates from both countries are vertically analyzed with all countries over the world by rank, as portrayed in Figures 1 and 2.

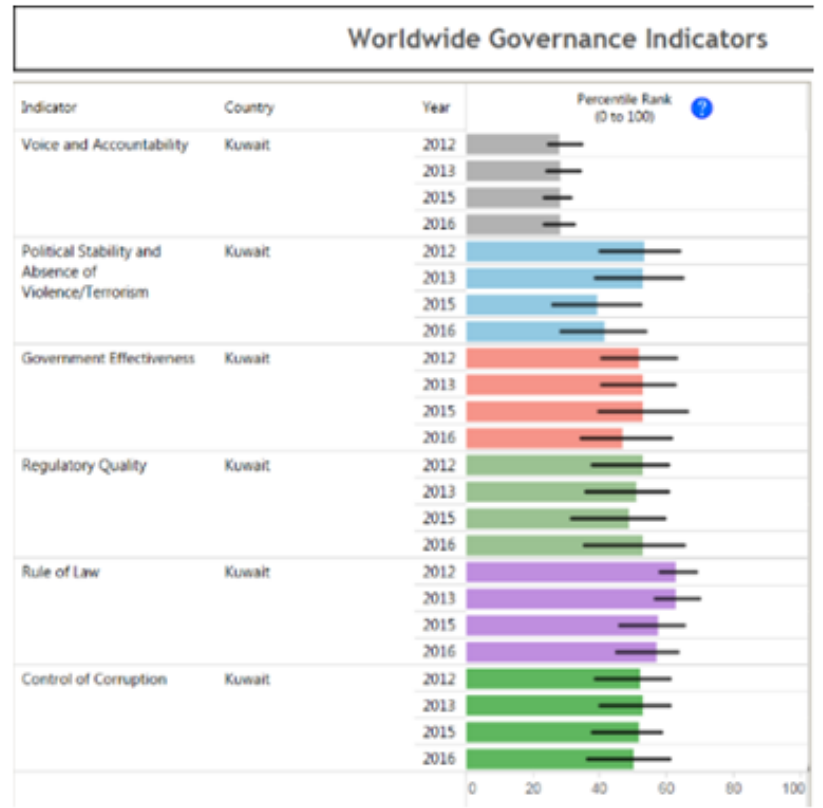

Figure 1 Kuwait Governance Indicator by Rank Source: World Bank (2016)

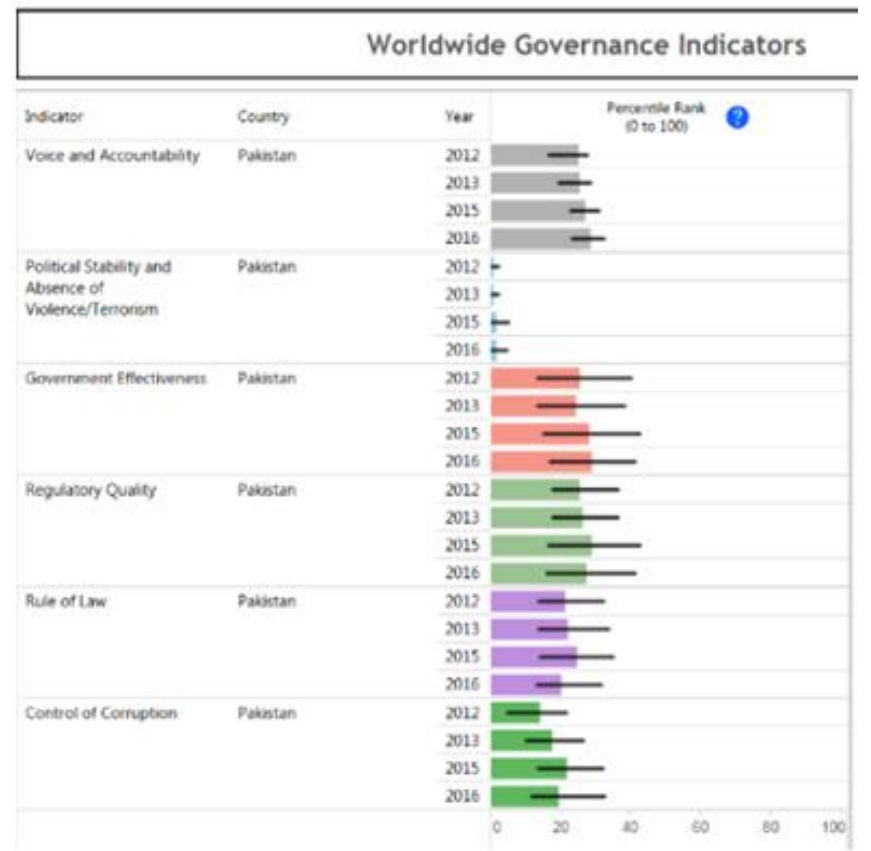

Figure 2. Pakistan Governance Indicator by Rank

In contrast, the Control of Corruption aspect in Pakistan based on governance indicator and supported by the Corruption Perception Index in 2016 is ranked at 116th (Table 3), which indicates a corrupt country.

Table 3. Kuwait and Pakistan: Corruption Perception Index by Rank

\begin{tabular}{|c|c|c|c|c|}
\hline \multirow{2}{*}{ Country } & \multicolumn{4}{|c|}{ Year } \\
\cline { 2 - 5 } & $\mathbf{2 0 1 6}$ & $\mathbf{2 0 1 5}$ & $\mathbf{2 0 1 3}$ & $\mathbf{2 0 1 2}$ \\
\hline Kuwait & 75 & 55 & 69 & 66 \\
\hline Pakistan & 116 & 117 & 127 & 139 \\
\hline
\end{tabular}

Source: (World Bank, 2016) 
Align with the survey of Transparency International and research conducted by Farooq et al. (2013) reveal that the absence of accountability is the highest facets of corruption factors then monopoly power, and so on. Moreover, accountability in both countries shows the negative sign, which means there is an indication of inadequate disclosure in both countries (Abdelsalam, 2015). Globally, Islamic Finance in 2016 shows a downward trend (Figure 4) from Zawya source, even though Kuwait still has better performance of IFDI indicators in Islamic finance development than Pakistan.

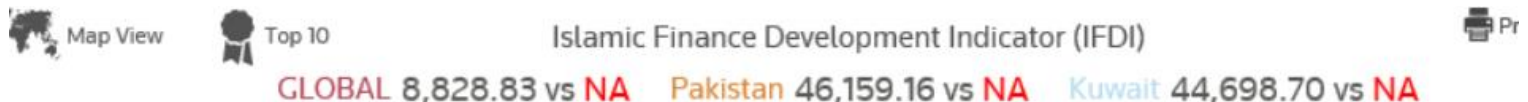

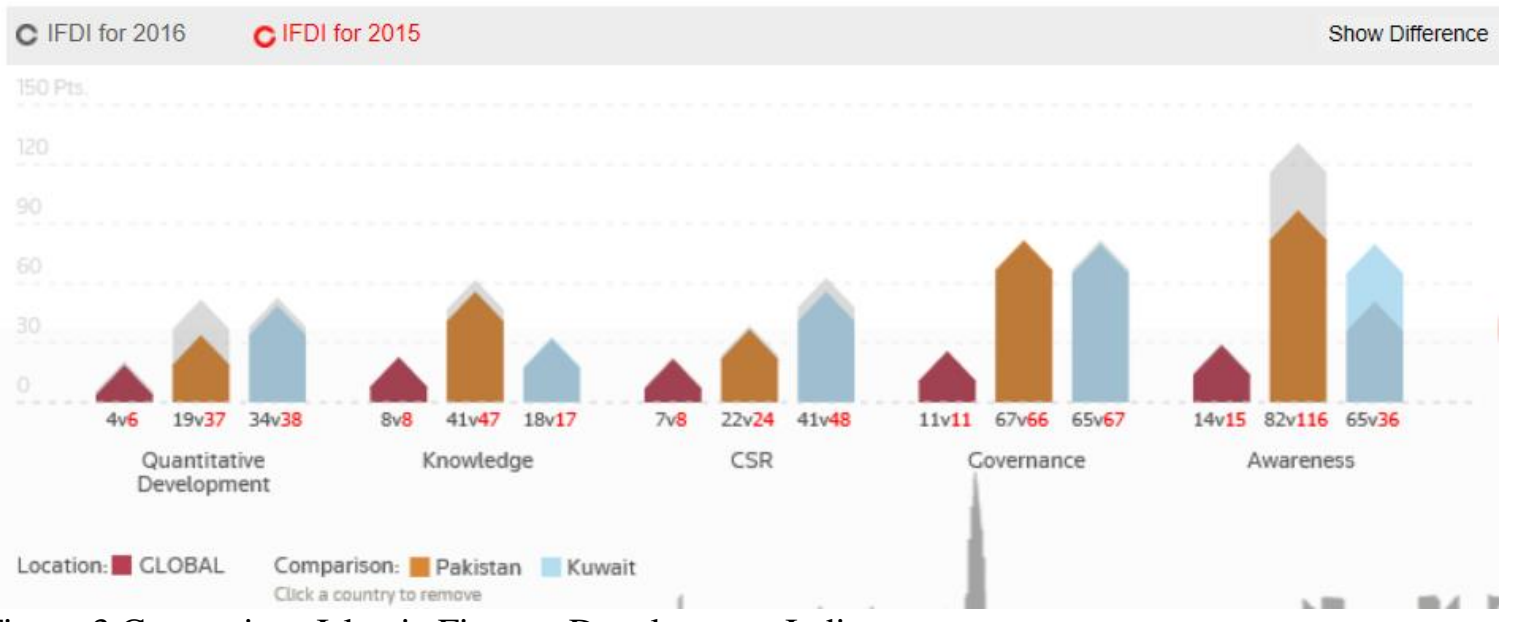

Figure 3 Comparison Islamic Finance Development Indicator

Source: (Zawya., 2018)

\section{Culture Analysis}

Culture is considered an essential element in understanding how social system changes due to the effect of norms and values of such system and behavior groups interaction within and across systems (Harrison and McKinnon, 1986). (Gray, 1988) argues there is a correlation between cultural dimension and accounting value in Figure 4 that represent Kuwait (WB) with a high score on power distance (PD) dimension than Pakistan (BIP), which implied that the level of PD would affect the work environment between managers and staffs.

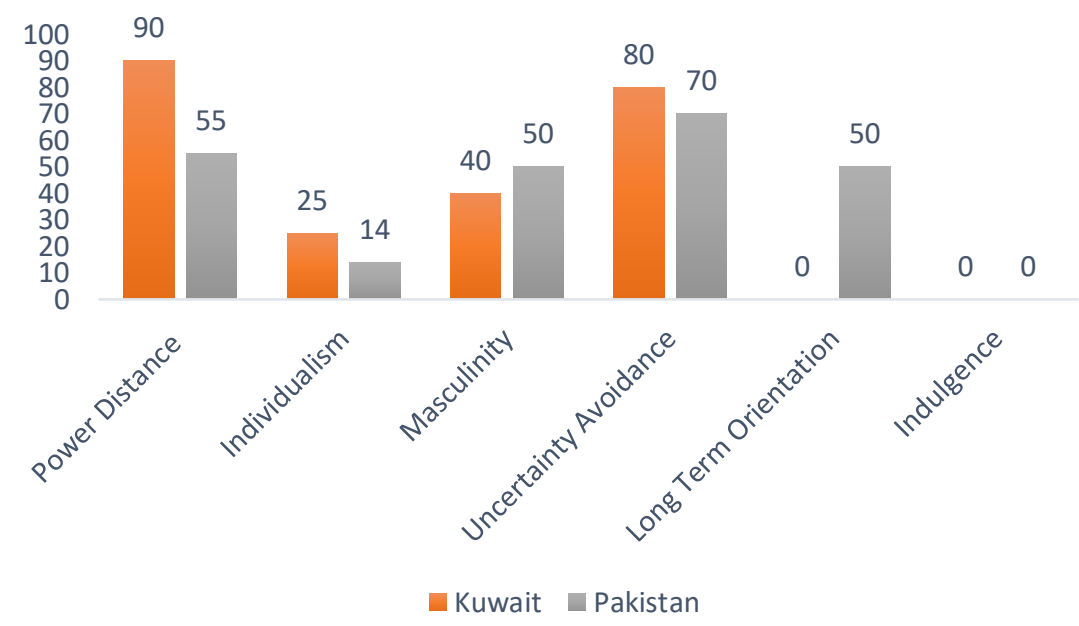

Figure 4 Hofstede Country Score - Comparison Kuwait and Pakistan

Source: (Hofstede Insight, 2018) 
Also, Kuwait and Pakistan show the same pattern regarding individualism (25 and 14) and uncertainty avoidance ( 80 and 70 ), respectively. Both banks have a low score, which is considered as a collectivistic society and prefer to avoid uncertainty.

\section{Internalization}

BankIslami Pakistan branches operate in 105 cities of the country, and the Bank shares are quoted on the Pakistan Stock Exchange Limited (formerly Karachi Stock Exchange Limited). As well as WB which listed in Kuwait Stock Exchange with ten branches in the city. This indicates the most accounting value both of banks influenced by their original culture.

\section{Company Analysis}

Ownership Structure

The shareholders of BIP was established as the public shareholding company (listed on a stock exchange) and some private ownership in Table 4 and 5. The major owners of BIP are three institutions, with a total of $77.10 \%$ who give influence to the company. Then, WB's major shareholders are owned by the government of Kuwait, represented by Kuwait Investment Authority at around 24\%, and give better performance due to increased efficiency asset management. This ownership structure indicates low agency cost (type 1) because the management team reduces the agency cost through dividend policy mechanism (Rozeff, 1982).

Further explanation of governance aspects that include the board of directors, external auditor and quality report, sharia supervisory board, CSR, and environmental performance will be discussed in the next section.

\section{Financial Performance}

\section{CAMEL Analysis}

The data that comply with CAMEL's analysis is presented in Table 4.

Table 4. CAMEL Ratio

\begin{tabular}{|l|c|c|c|c|c|c|c|c|c|c|c|c|}
\hline \multirow{2}{*}{ Ratio } & \multicolumn{3}{|c|}{ IB's Worldwide } & \multicolumn{3}{c|}{ Banklslami Pakistan } & \multicolumn{5}{c|}{ Warma Bank } \\
\cline { 2 - 14 } & $\mathbf{2 0 1 6}$ & $\mathbf{2 0 1 5}$ & $\mathbf{2 0 1 3}$ & $\mathbf{2 0 1 2}$ & $\mathbf{2 0 1 6}$ & $\mathbf{2 0 1 5}$ & $\mathbf{2 0 1 3}$ & $\mathbf{2 0 1 2}$ & $\mathbf{2 0 1 6}$ & $\mathbf{2 0 1 5}$ & $\mathbf{2 0 1 3}$ & $\mathbf{2 0 1 2}$ \\
\hline Capital Adequacy & & & & & & & & & & & & \\
\hline Total Capi tal Ratio & 33,68 & 27,84 & 26,81 & 20,00 & 13,63 & 12,84 & 15,7 & 15,48 & 18,00 & 26,07 & 47,54 & 77,23 \\
\hline Asset Quality & & & & & & & & & & & & \\
\hline Loan Loss Prov/Net Int Rev $\%$ & 46,78 & 15,5 & 35,69 & 50,24 & 1,70 & 13,83 & 1,60 & 1,44 & 30,84 & 24,97 & 44,58 & 35,24 \\
\hline Management Ability & & & & & & & & & & & & \\
\hline Cost to Income Ratio & 69,98 & 62,72 & 87,24 & 49,27 & 85,71 & 100,63 & 86,78 & 80,38 & 66,11 & 77,62 & 111,52 & 110,02 \\
\hline Earnings Ability & & & & & & & & & & & & \\
\hline Net Interest Margin & 3,3 & 3,88 & 3,25 & 4,09 & 1,25 & 1,15 & $-0,37$ & $-0,38$ & 1,75 & 1,79 & 2,03 & 1,55 \\
\hline Return On Avg Assets (ROAA) & 0,90 & 1,44 & 1,5 & 1,24 & 0,36 & $-0,08$ & 0,23 & 0,47 & 0,27 & 0,15 & $-1,18$ & $-1,08$ \\
\hline Return On Avg Equity (ROAE) & 11,63 & 14,05 & 13,00 & 2,68 & 5,81 & $-1,35$ & 3,15 & 5,68 & 2,75 & 1,09 & $-3,98$ & $-1,93$ \\
\hline Liquidity & & & & & & & & & & & & \\
\hline Net Loans/Dep \& ST Funding & 97,84 & 74,1 & 84,4 & 57,75 & 48,59 & 44,00 & 49,32 & 41,76 & 80,8 & 80,23 & 69,89 & 66,47 \\
\hline
\end{tabular}

Source: Orbis (2018)

\section{Capital}

The capital adequacy ratio (CAR) of the two banks is employed to analyze the banks' performance in their capital (Ferrouhi, 2014). Figure 5 illustrates that both banks complied with the minimum CAR requirement as mandated by the BASEL III standard of $12 \%$ but scored lower than the average CAR of Islamic banks worldwide. 


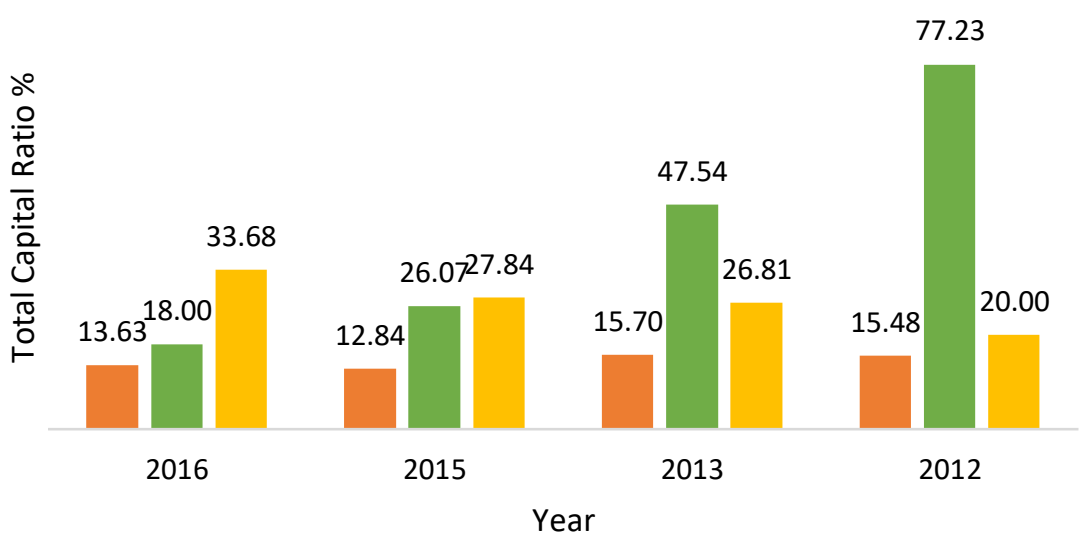

Figure 5 Capital Adequacy

Source: (Orbis, 2018)

WB's CAR was higher than BIP; however, both banks show a downward trend from 2012 to 2016 with a ratio of $18 \%$ and $13,63 \%$ respectively in the last year. Therefore, increasing CAR is required for both banks since it has positive significance with the soundness of banks' financial condition, whereby the negative ratio will result in insolvency (Dincer et al., 2011).

Asset

Hassan and Bashir (2003) reveal loss provision over net interest revenue can be used as indicators to calculate asset quality. The lower the ratio, the better is the loan's risk of the bank. WB's maintained the high-risk level to be more than $44 \%$ in 2013, as portrayed in Figure 6. However, BIP's ratio rose to $13,83 \%$ in 2015 when experiencing negative performance. Also, both banks are scored lower than other Islamic banks' ratios. This result implies both banks are successfully sustained their loan's risk at the ower rate and should preserve this tendency, especially BIP.

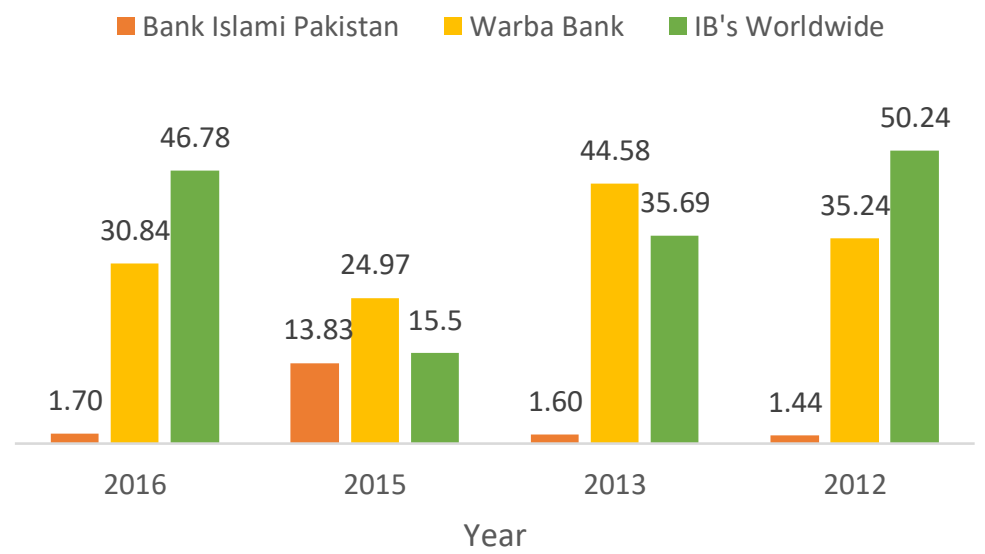

Figure 6 Asset Quality

Source: (Orbis, 2018)

\section{Management}

Mathuva (2009) defines management's quality is assessed through its efficiency as determined by the cost to income ratio. The banks will be more efficient with the lower ratio. WB's ratio relatively plunged from $110,02 \%$ to $66,11 \%$, which was lower than the average Islamic bank's efficiency in 2016. 
The result is portrayed in Figure 7, which indicates that WB commenced efficiently managing their expenses. However, BIP showed a higher ratio for four years than average IB cost efficiency. Hence, both banks should adequately control the cost to increase their profit.

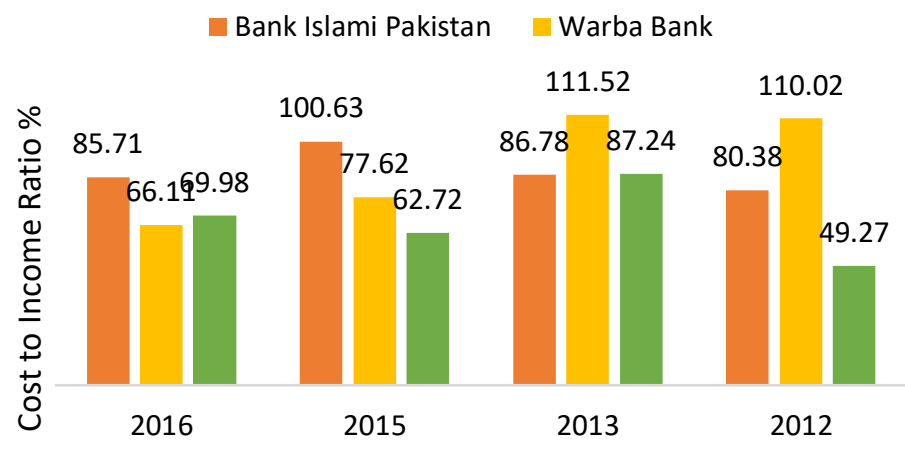

Figure 7 Asset Quality

Source: (Orbis, 2018)

\section{Earning}

Measuring the profitability level or the bank's earnings can be derived from "net interest margin (NIM), return on average asset (ROAA), and return on average equity (ROEE)" (Bikker, 2010). In Figure 8, 9, and 10, BIP showed better performance in their ROAA and ROEE. BIP had higher ROAA in 2012 and 2016, although it reached a slight minus in 2015. Then, WB performed worse and achieved a significant minus $(-1,18 \%)$ ROAA in 2013 and 2012. These two banks' ROAA ratio was lower than the average IB. The same trend occurred with BIP that performed minus in ROAE to $-1,35 \%$ in 2015 , while WB dropped by twofold in 3013 and 2012 before rising at 2,75 in 2016. Furthermore, BIP demonstrated the negative numbers of their NIM in 2013, which differ with WB, who contribute good performance. Hence, BIP has better earnings ability than WB based on the above ratios, which reflects better performance.

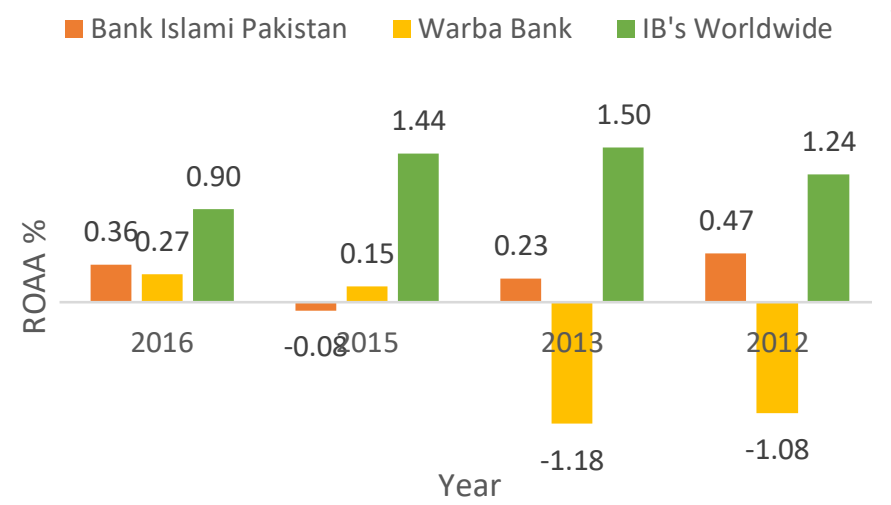

Figure 8. Earning ROAA

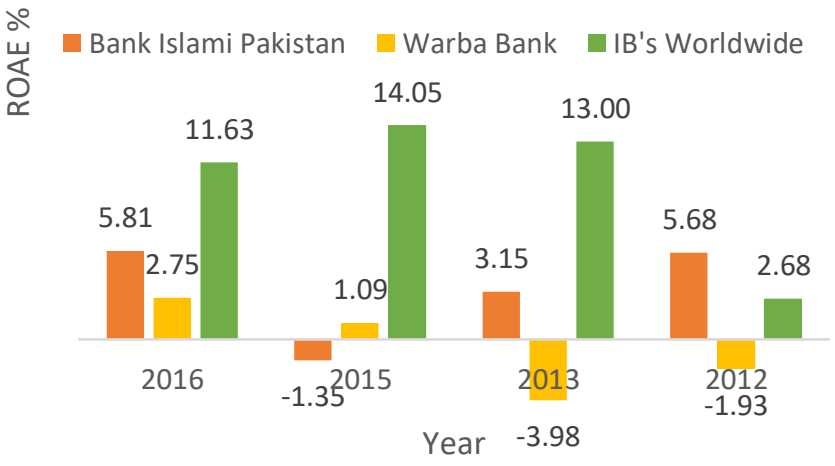

Figure 9 Earning ROAE 


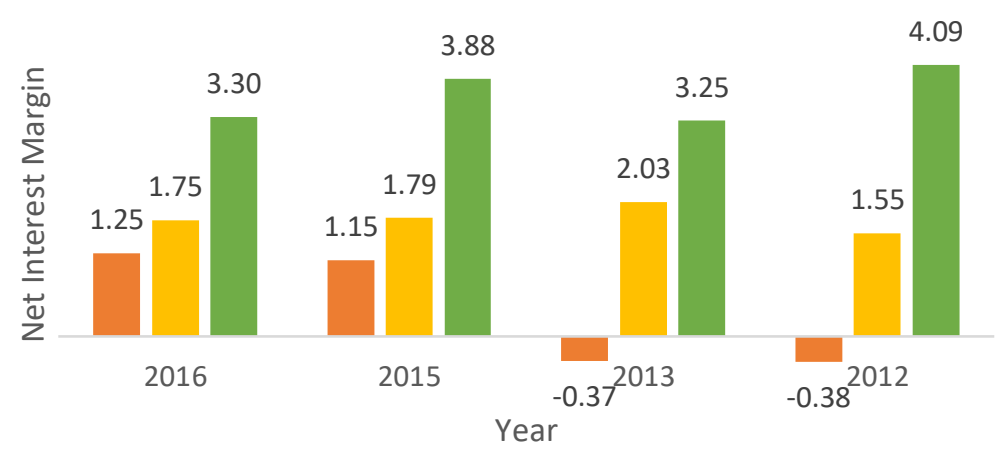

Figure 10 Earning NIM

Source: (Orbis, 2018)

\section{Liquidity}

The liquidity measurement is derived from the total funding over the degree of short-term reliance (Ferrouhi, 2014). The higher the number of this ratio reflects the less liquidity of the banks. BIP showed a lower ratio than WB and overall Islamic banks, which indicates better liquidity, as portrayed in Figure 11. The two banks also presented the rising trend of this ratio that similar to the global Islamic banks that tended to increase year by year.

\section{Bank Islami Pakistan Warba Bank घIB's Worldwide}

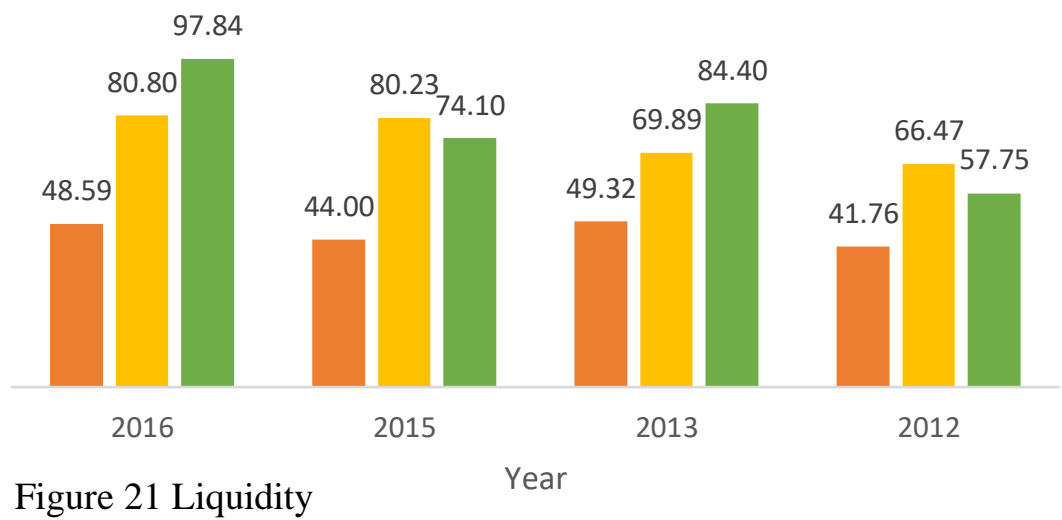

Source: (Orbis, 2018)

\section{Earning Quality}

The data of earnings quality is analyzed from the EIKON's database, as depicted in Figures 12 and 13. WB is scored higher by 34 than BIP that only achieved 20 in their earnings quality. However, these two banks' score is lower than the industry median that is 49 . WB has better earnings quality even though it has lower earnings ability than BIP from 2015 to 2016. The appointment of two Big-Four audit firms is affecting their earnings quality score, and this correlates with Ball and Shivakumar (2005) research. 


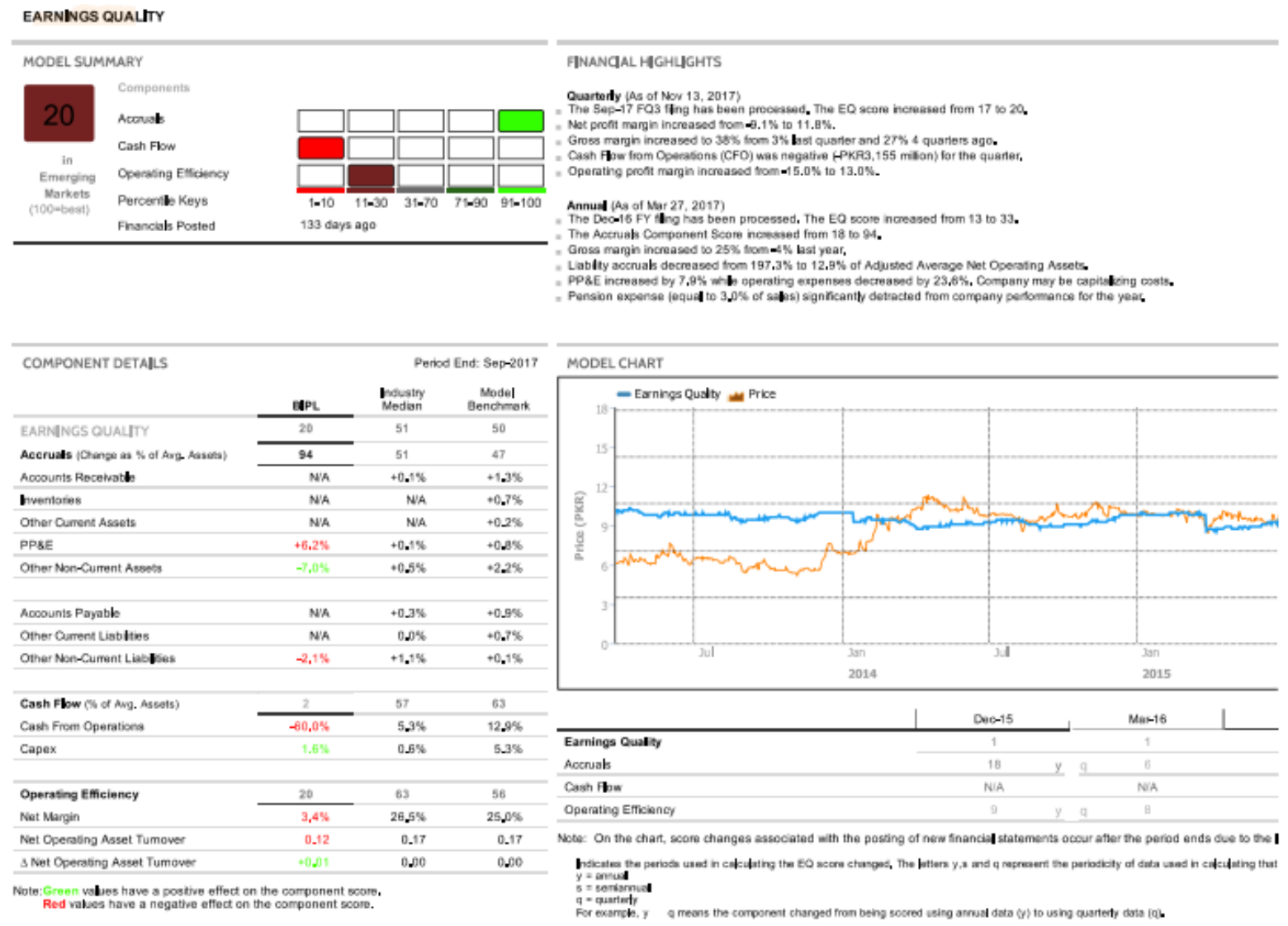

Figure 12. Bank Islami Pakistan Earnings Quality

Source: (Zawya., 2018)

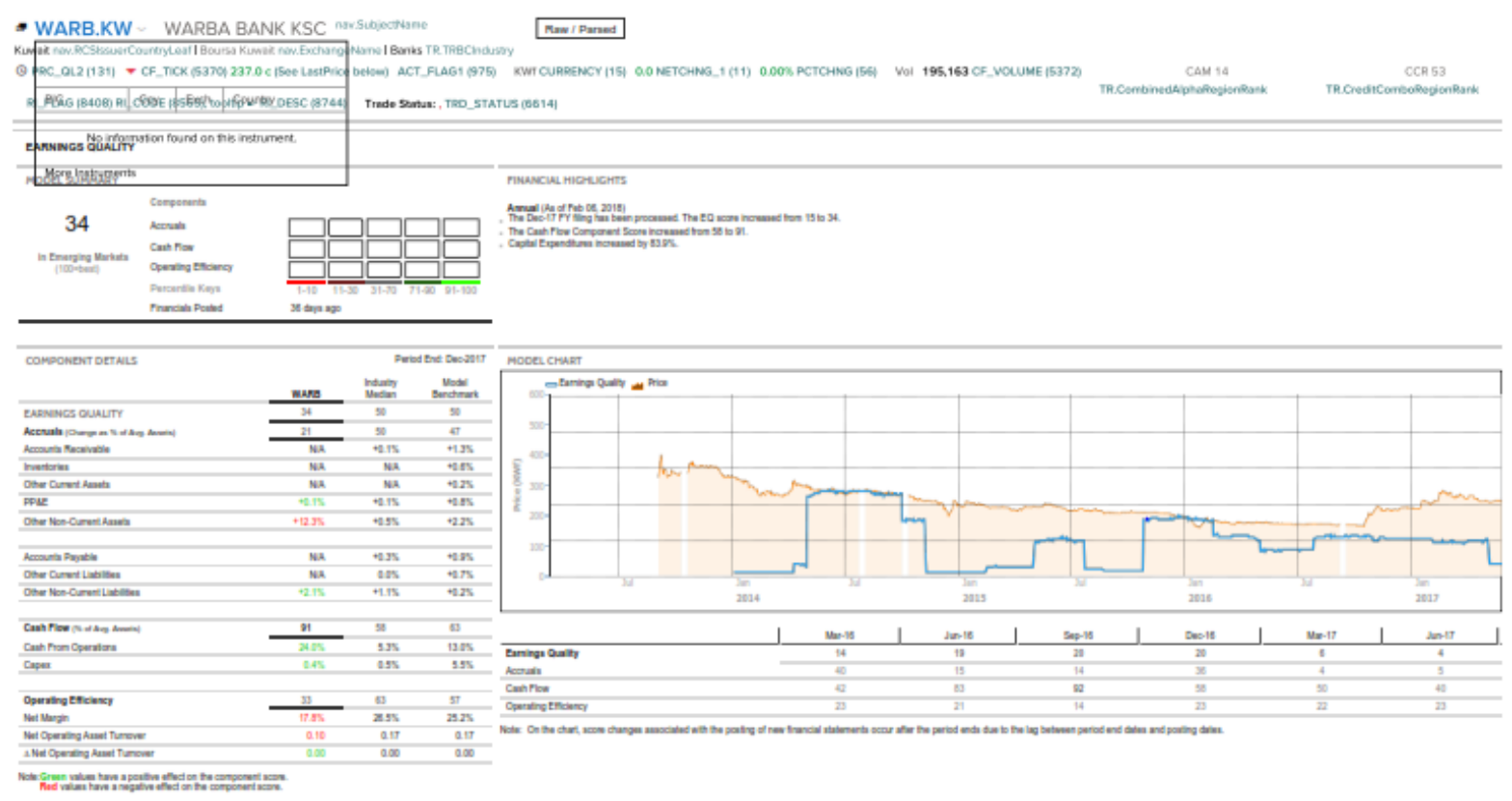

Figure 13. Warba Bank Earnings Quality

Source: (Eikon., 2016) 


\section{Narrative Disclosure}

This section will examine the presence of impression management, self-presentational dissimulation, and retrospective sense-making in the bank's annual report by Diction and LWIC software.

Table 8. Narrative Quality Score from Diction and LIWC

\begin{tabular}{|l|c|c|c|c|c|c|c|c|}
\hline \multirow{2}{*}{\multicolumn{1}{|c|}{ Indicators }} & \multicolumn{4}{|c|}{ BankIslamiPakistan } & \multicolumn{4}{c|}{ Warba Bank } \\
\cline { 2 - 10 } & $\mathbf{2 0 1 6}$ & $\mathbf{2 0 1 5}$ & $\mathbf{2 0 1 3}$ & $\mathbf{2 0 1 2}$ & $\mathbf{2 0 1 6}$ & $\mathbf{2 0 1 5}$ & $\mathbf{2 0 1 3}$ & $\mathbf{2 0 1 2}$ \\
\hline Complexity & 5,31 & 5,17 & 5,07 & 5,02 & 5,43 & 5,24 & 4,88 & 4,53 \\
\hline Optimism & 50,04 & 52,03 & 40,09 & 53,14 & 61,05 & 58,54 & 57,35 & 53,78 \\
\hline Certainty & 47,2 & 45,03 & 48,4 & 47,14 & 44,99 & 46,54 & 44,58 & 46,11 \\
\hline Word Count & 736 & 761 & 747 & 796 & 766 & 786 & 786 & 824 \\
\hline Positive Emotion & 3,1 & 2,9 & 2,9 & 2,8 & 5,3 & 5,4 & 5,4 & 3,5 \\
\hline Negative Emotion & 0,4 & 0,4 & 0,5 & 0,7 & 0,6 & 0,5 & 0,5 & 0,6 \\
\hline Self-Reference & 0,12 & 0,58 & 0,25 & 0,12 & 5,87 & 3,0 & 3,0 & 0,62 \\
\hline Cognitive Processes & 5,0 & 4,4 & 6,8 & 5,7 & 4,9 & 4,7 & 5,0 & 6,2 \\
\hline
\end{tabular}

\section{Optimism and Certainty}

Healy and Wahlen (1999) convey impression management is viewed as constituting inconsistency between the managerial view of organizational performance and the outlooks publicly to corporate narrative documents. Regarding optimism and certainty, (DICTION, 2015) defines the "optimism" as an endorsing language to underline their positive implications. However, it can results in bias disclosure if performance different from their language and leads to attribution theory (Heider, 1958; Davis et al., 2012). Certainty score is presented in Figure 20 and Table 10. BIP tends to utilize less precise language from to 2012 to 2016 and use several optimism words that fluctuate every year. This fact is related to the negative performance of BIP, especially in 2015. WB has stable optimism and utilizes slightly more specific words, which indicated a lower impression management tendency. On the contrary, WB experienced high optimism proxy when profitability performance is negative in 2013 and 2012. It could be analyzed from the inconsistency of the chairman's statement, which results that there is an indication for blaming the external parties toward their negative performance.
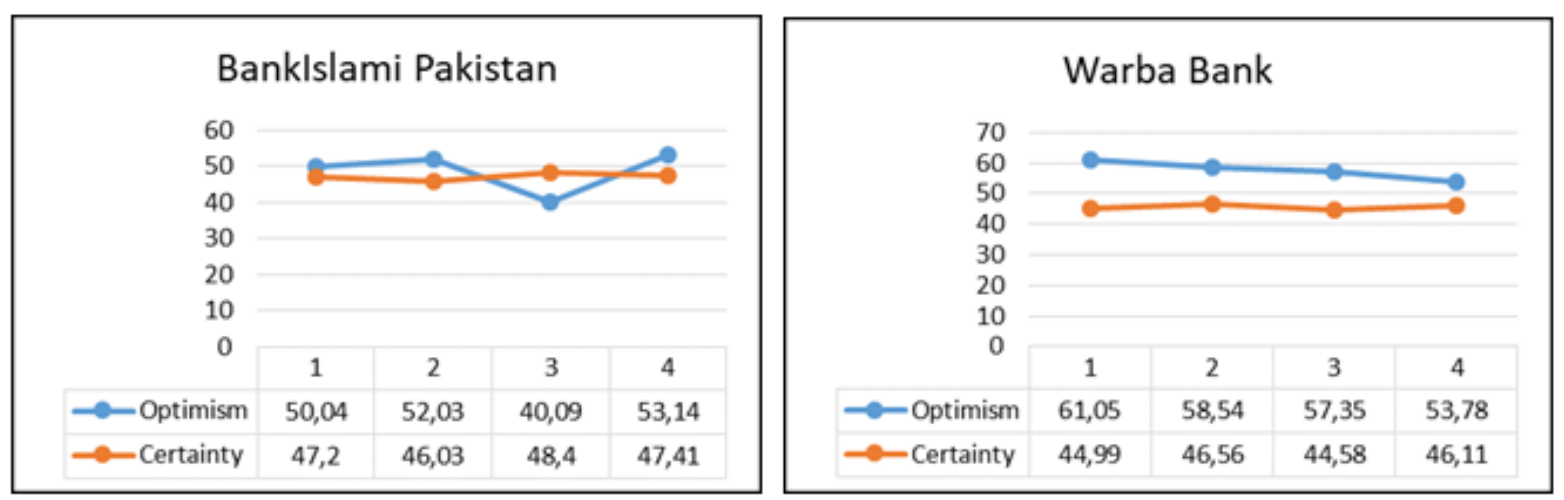

Figure 14. Comparisons between BIP dan WB regarding optimism and certainty

\section{Positive and Negative Emotion}

The "positive and negative" words are utilized as a proxy for the enrichment of the institution's performance in the report (Merkl-Davies et al., 2011). The positive emotion reflects positive performance. In this figure, BIP used less positive emotion and less negative emotion words compared to WB from 2012 to 2016. WB showed more use of positive emotion words as same as in 2015 and 2013, which it is not in line with the loss profitability amount. Hence, WB performs retrospective sensemaking, which means bias in the narrative with reality (Merkl-Davies et al., 2011). Thus, BIP is suspected to implement impression management through the usage of the less positive and more negative words, which is correlated with their minus earnings ability. 

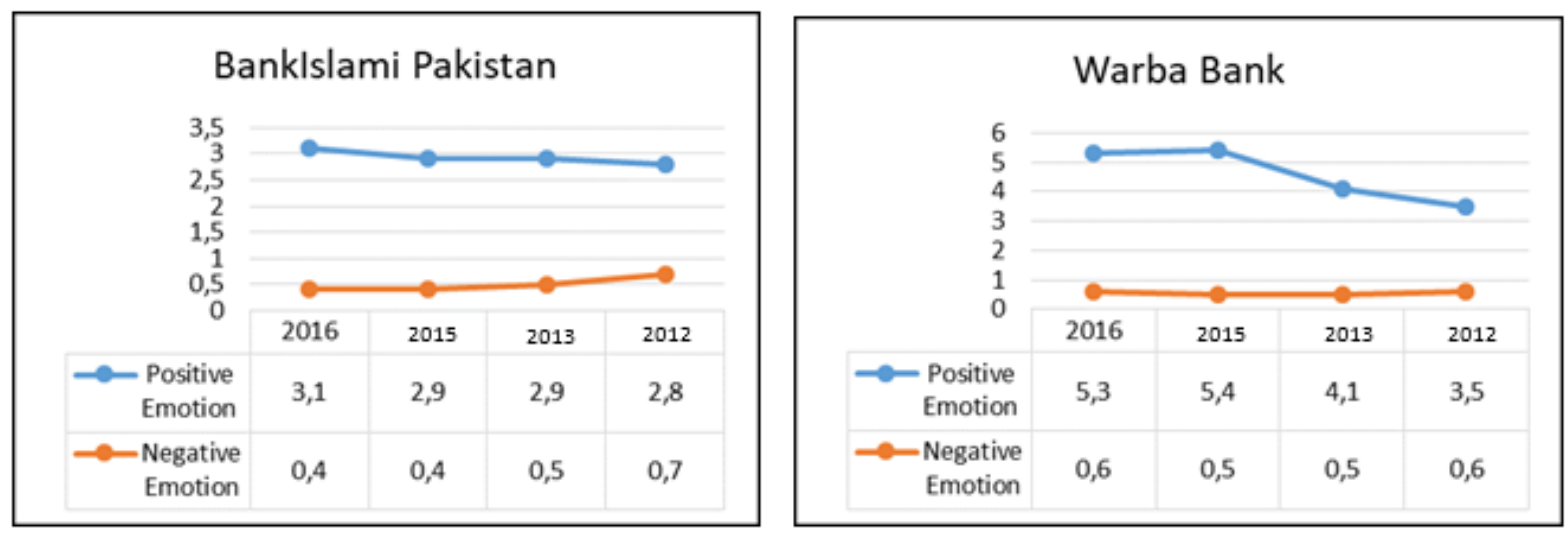

Figure 15. Comparisons between BIP dan WB regarding positive and negative emotion

\section{Word Count, Cognitive Complexity, and Self-Reference}

Bloomfield (2008) and Newman et al. (2003) state that document length and negative emotion in negative financial performance have probability the complexity of the cognitive process and deliver discomfort experience when engaging in deception. LIWC results in 2012. WB shows the highest score in both aspects, which is word count and cognitive process up to 824 and 6.2, respectively than BIP and other years. Therefore, WB is assumed to attribute more in impression management than BIP due to the negative financial performance from 2012 to 2013.
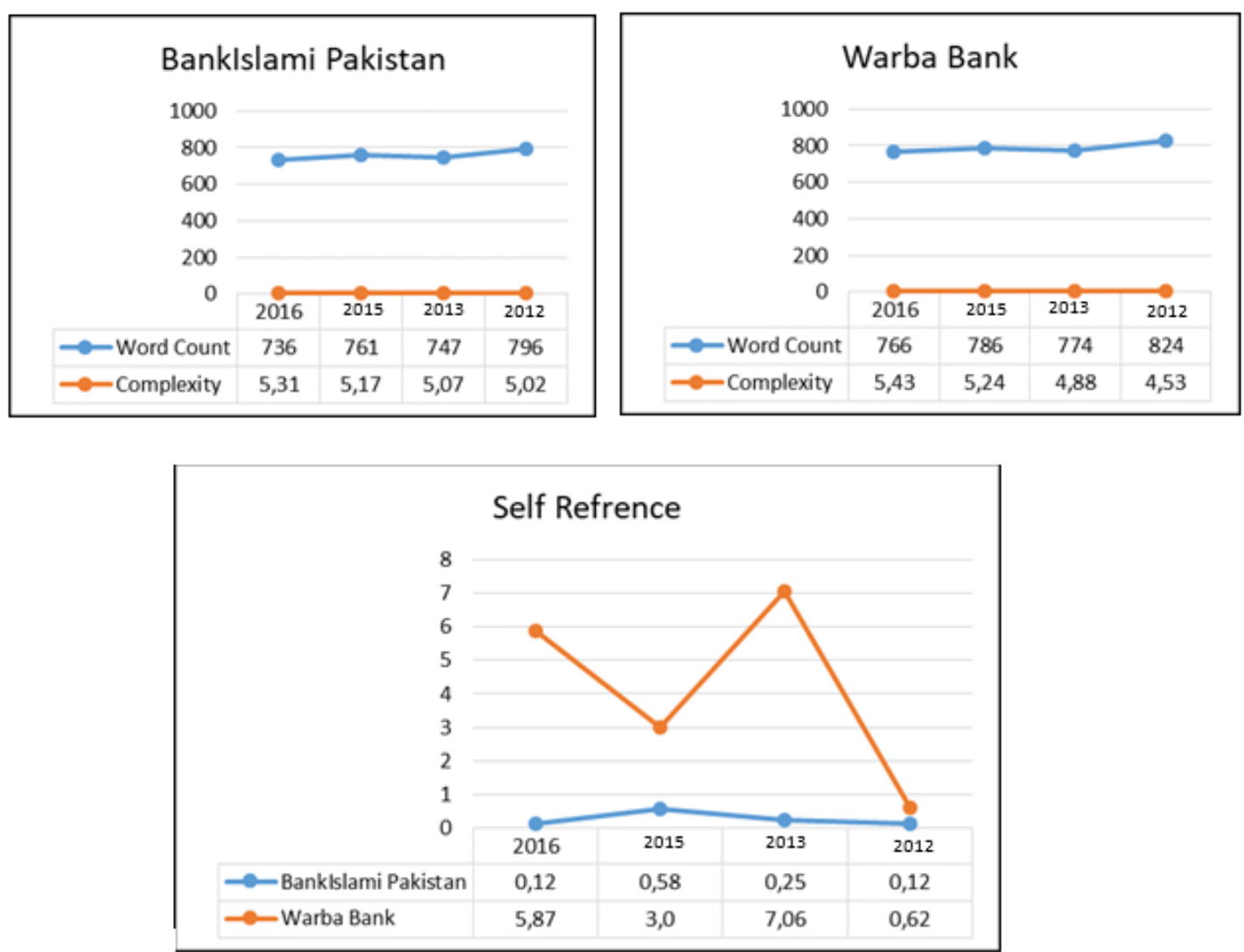

Figure 16. Comparisons between BIP dan WB regarding Word Count, Cognitive Complexity, and SelfReference 


\section{Discussions}

Relating to Kauffman's theory that illustrates the legal/institutional environment, these six aspects illustrate Pakistan has a better political environment than Kuwait such as government ability to formulate and implement policy, and quality of public service. The higher score power distance by Kuwait also influence uniformity value in implementing laws, codes of character, and professionalism in which Pakistan people have higher trust in each other. Refer to individualism, and uncertainty avoidance, both of country have the same patterns that means they have rigid behaviour codes (written rules and regulation) and highly consider secrecy aspect especially Kuwait in which influence accounting value such as low in disclose information. Some company analysis regarding governance bodies discuss as followed:

\section{Governance Bodies (Board of Directors)}

BIP boards' composition was constituted of independent, executive, and non-executive members to prevent agency issues (Kumar and Sivaramakrishnan, 2008). Both banks employed multiple directorship that can induce agency problems. Looking at directors' educational backgrounds, most of them have graduated with a master's degree. However, most of WB directors graduated from the United States that can influence transparency and perception of the bank system. BIP and WB have a similar committee structure in audit, risk management, and executive committee. Nonetheless, BIP differs in I.T. and compensation committee while WB has a separate governance committee. In the leadership context, those two banks have the different boards in positioning chairman and CEO. Furthermore, WB employed one person as Vice and CEO position. The number of the meeting also classified frequent as more than twice a year. Although BIP gives information about meeting agenda, board meeting frequency will be associated negatively to increase firm value as argued by (Vafeas, 1999).

It is reported from the annual report that BIP board has formed an HR and Remuneration Committee with five members and dominant by non-executive directors. Then, the nomination and remuneration committee at WB assists BOD in ensures the efficiency of recruitment and rewards policies practiced in the bank.

\section{External Auditor and Report Quality}

Annual reports from both banks stated "unqualified" opinion during 2012-2016 and adopting the same IFRS standard, which means that the financial statements are accurate and comply with the financial reporting framework (Rezaee, 2002). BIP employed a chartered accountant as an external auditor (EY Ford Rhodes), which is one of the auditor members linked with the PricewaterhouseCoopers network. Even though BIP reporting quality contradict with Al-Ajmi (2009) arguments that non-Big-Four firm as the auditor will provide low-quality disclosure. While WB hired two Big-Four firms as auditors (EY and KPMG), who expected to offer higher perceived disclosure quality due to their prominent and recognizable names (Mitton, 2002). Both banks provide audit reports published on the website regularly; however, the annual audited account to a shareholder can be obtained through request form or based on shareholders' demand. They also implement good governance, and the independence of auditors reflected from the appointment of the external auditor is based on the audit committee and board decision. However, both banks do not rotate the auditors every three years as mandated by regulation.

Different from WB, who do not disclose the audit fees, BIP discloses that amounted to 4,363 USD. Audit fees, according to Khoo and Chiat (2010) is not mandatory to publish, although it will enhance the financial transparency in Islamic banks. The study from Leventis et al. (2018) reveals that the level of religiosity has decreased the audit pricing in more religious business firms. It is expected that Islamic banks have a higher religiosity level; hence, the audit fees in these institutions are relatively adjustable.

\section{Sharia Supervisory Board (SSB) Report}

Looking at SSB composition, both banks used the regulation standard issued by AAOIFI, where should be three minimum members of SBB. Considering of duties and independency of the SSB roles, one issue has arisen due to the duality roles of BIP SSB chairman is employed by other Islamic banks. As a result, this issue could deteriorate the reputation and legitimacy of the reports Ahmed (2011) and 
harm the sustainability of Islamic banks in the future. Regarding SSB background, BIP aligns with legitimacy theory by Safieddine (2009) that their SSBs' education and work experience should be deep understanding in sharia background rather than financial background, which contradicts with WB SSB information.

\section{CSR and Social Environmental Performance}

CSR score is based on Belal et al. (2015) checklist. Based on Table 6, BIP has higher disclosure in social and ethical than WB. Both banks showed improvement in their disclosure, specifically WB, increase more than $15 \%$ in 2016. These two banks have different methods of social exposure as they are following the IFRS that does not require specific disclosure pertaining to sharia practice. As summarised in Table 6 (Appendices 1), BIP disclosed more in the CSR report since Islamic banks are demanded to implement more in social responsibilities (Haniffa and Hudaib, 2007). BIP delivers "Charity Funds Utilization Report" that includes sharia non-compliance funds' sources and its allocation disclosed Islamic commitment through Zakah funds, while WB described it generally in chairman statement. However, both banks do not recognize the environmental issue, and they do not have an ESG score from Asset4 or MSCI databases.

\section{Conclusion, Limitation, and Future Research Directions}

In conclusion, both Islamic banks have similar culture conditions, whereas BIP provides more information regarding Islamic social program disclosure, which can attract investors. According to general financial statement disclosure, both banks fulfill more than half conventional accounting standards, whereas the number of Islamic value items should be increased by banks. However, there are bad political affairs in the corruption level and role-duality within the board structure. It can contribute to the lack of transparency and the absence of independence. On the other hand, WB has a better performance in financial analysis and contributes to IFDI indicators, which Kuwait is higher than Pakistan. Some theories are proved by WB cases such as attribution theory that WB tends to blame other parties when having negative income and the correlation of Big-Four audit firm towards accountability annual report.

However, the findings of this study are subject to several limitations. First, our study focus on comparing and analyzing the suitability of Islamic bank annual reports to sharia regulation in the same type of country, which are Pakistan and Kuwait. Further research may employ one type of developing country and developed country to obtain a significant result from the differences code of regulation, government quality, and so on. Second, our research focus on the content analysis method that gathered from the annual report states. Future research may consider more empirical approaches, such as indepth interviews to core management levels or employees.

\section{References}

Abdelsalam, O. (2015), Audit and Governance of Islamic Financial Institutions, No. ECON43215, Durham UK.

Ahmed, H. (2011), "Risk management assessment systems: an application to Islamic banks", Islamic Economic Studies, Vol. 19 No. 1, pp. 63-68.

Al-Ajmi, J. (2009), "Audit firm, corporate governance, and audit quality: Evidence from Bahrain", Advances in Accounting, Vol. 25 No. 1, pp. 64-74.

Ball, R. and Shivakumar, L. (2005), "Earnings quality in UK private firms: comparative loss recognition timeliness", Journal of Accounting and Economics, Vol. 39 No. 1, pp. 83-128.

Beasley, M.S. (1996), "An empirical analysis of the relation between the board of director composition and financial statement fraud", Accounting Review, pp. 443-465.

Belal, A.R., Abdelsalam, O. and Nizamee, S.S. (2015), "Ethical Reporting in Islami Bank Bangladesh Limited (19832010)", Journal of Business Ethics, Vol. 129 No. 4, pp. 769-784.

Bikker, J.A. (2010), "Measuring performance of banks: an assessment", The Journal of Applied Business and Economics, Vol. 11 No. 4, p. 141.

Bloomfield, R. (2008), "Discussion of 'annual report readability, current earnings, and earnings persistence", Journal of Accounting and Economics, Vol. 45 No. 2-3, pp. 248-252.

Chapra, M.U. and Ahmed, H. (2002), “Corporate Governance in Islamic Financial Institutions”, IDB Islamic Research and Training Institute, Vol. 6.

Davis, A.K., Piger, J.M. and Sedor, L.M. (2012), "Beyond the numbers: Measuring the information content of earnings press release language”, Contemporary Accounting Research, Vol. 29 No. 3, pp. 845-868.

DICTION. (2015), "DICTION 7.1 Help Manual”, Digitext, inc. 
Dincer, H., Gencer, G., Orhan, N. and Sahinbas, K. (2011), “A performance evaluation of the Turkish banking sector after the global crisis via CAMELS ratios”, Procedia-Social and Behavioral Sciences, Vol. 24, pp. 1530-1545.

Eikon., T.R. (2016), "Earnigns Quality and Financial Ratios”, Warba Bank (2012-2016), available at: Durham Business School Library (accessed 21 March 2018).

Farooq, A., Shahbaz, M., Arouri, M. and Teulon, F. (2013), “Does corruption impede economic growth in Pakistan?”, Economic Modelling, Vol. 35, pp. 622-633.

Ferrouhi, E.M. (2014), "Moroccan Banks analysis using camel model", International Journal of Economics and Financial Issues, Vol. 4 No. 3, pp. 622-633.

Gray, S.J. (1988), "Towards a theory of cultural influence on the development of accounting systems internationally", Abacus, Vol. 24 No. 1, pp. 1-15.

Haniffa, R. and Hudaib, M. (2007), "Exploring the ethical identity of Islamic banks via communication in annual reports”, Journal of Business Ethics, Vol. 76 No. 1, pp. 97-116.

Harrison, G.L. and McKinnon, J.L. (1986), "Culture and accounting change: A new perspective on corporate reporting regulation and accounting policy formulation”, Accounting, Organizations and Society, Vol. 11 No. 3, pp. 233252.

Hassan, M.K. and Bashir, A.H.M. (2003), "Determinants of Islamic banking profitability”, 1oth ERF Annual Conference, Morocco.

Healy, P.M. and Wahlen, J.M. (1999), "A review of the earnings management literature and its implications for standard setting", Accounting Horizons, Vol. 13 No. 4, pp. 365-383.

Heider, F. (1958), The Psychology of Interpersonal Relations, Wiley, New York.

Hofstede Insight. (2018), "Hofstede's Cultural Dimension Kuwait and Pakistan", available at: https://www.hofstedeinsights.com/product/compare-countries/ (accessed 23 March 2018).

Kaufmann, D., Kraay, A. and Mastruzzi, M. (2011), "The worldwide governance indicators: methodology and analytical issues", Hague Journal on the Rule of Law, Vol. 3 No. 2, pp. 220-246.

Khoo, T.A. and Chiat, H.S. (2010), “Audit Fees: To Disclose or Not to Disclose?”, Business Times.

Kumar, P. and Sivaramakrishnan, K. (2008), "Who monitors the monitor? The effect of board independence on executive compensation and firm value", The Review of Financial Studies, Vol. 21 No. 3, pp. 1371-1401.

Leventis, S., Dedoulis, E. and Abdelsalam, O. (2018), “The impact of religiosity on audit pricing”, Journal of Business Ethics, Vol. 148 No. 1, pp. 53-78.

Mathuva, D.M. (2009), "Capital adequacy, cost income ratio and the performance of commercial banks: The Kenyan Scenario", The International Journal of Applied Economics and Finance, Vol. 3 No. 2, pp. 35-47.

Merkl-Davies, D.M., Brennan, N.M. and McLeay, S.J. (2011), "Impression management and retrospective sensemaking in corporate narratives: A social psychology perspective”, Accounting, Auditing $\mathcal{E}$ Accountability Journal, Vol. 24 No. 3, pp. 315-344.

Mitton, T. 4. (2002), "A cross-firm analysis of the impact of corporate governance on the East Asian financial crisis", Journal of Financial Economics, Vol. 64 No. 2, pp. 215-241.

Newman, M.L., Pennebaker, J.W., Berry, D.S. and Richards, J.M. (2003), "Lying words: Predicting deception from linguistic styles", Personality and Social Psychology Bulletin, Vol. 29 No. 5, pp. 665-675.

Orbis. (2018), "Orbis Bank Focus".

Rezaee, Z. (2002), Financial Statement Fraud: Prevention and Detection, John Wiley and Son, Inc, New York.

Rozeff, M.S. (1982), "Growth, beta and agency costs as determinants of dividend payout ratios", Journal of Financial Research, Vol. 5 No. 3, pp. 249-259.

Safieddine, A. (2009), "Islamic financial institutions and corporate governance: New insights for agency theory", Corporate Governance: An International Review, Vol. 17 No. 2, pp. 142-158.

Schein, E.H. (2004), Organizational Culture and Leadership, Jossey-Bass, San Fransisco.

Vafeas, N. (1999), "Board meeting frequency and firm performance”, Journal of Financial Economics, Vol. 53 No. 1, pp. 113-142.

World Bank. (2016), “Governance Indicators Kuwait and Pakistan (2012-2016)”.

Zawya., T.R. (2018), "Islamic Finance Development Indicator", available at: http://www.zawya.com/islamic-financedevelopment-indicator/ (accessed 15 April 2018). 